\title{
LC478, a Novel Di-Substituted Adamantyl Derivative, Enhances the Oral Bioavailability of Docetaxel in Rats
}

\author{
Seung Yon Han, Qili Lu, Kyeong Lee * and Young Hee Choi *(1) \\ College of Pharmacy and Integrated Research Institute for Drug Development, Dongguk University_Seoul, \\ 32 Dongguk-lo, Ilsandong-gu, Goyang-si, Gyonggi-do 10326, Korea; hsyglory@gmail.com (S.Y.H.); \\ luqili220@gmail.com (Q.L.) \\ * Correspondence: kaylee@dongguk.edu (K.L.); choiyh@dongguk.edu (Y.H.C.); Tel.: +82-31-961-5214 (K.L.); \\ $+82-31-961-5212$ (Y.H.C)
}

Received: 15 February 2019; Accepted: 14 March 2019; Published: 20 March 2019

check for updates

\begin{abstract}
P-glycoprotein (P-gp)-mediated efflux of docetaxel in the gastrointestinal tract mainly impedes its oral chemotherapy. Recently, LC478, a novel di-substituted adamantyl derivative, was identified as a non-cytotoxic P-gp inhibitor in vitro. Here, we assessed whether LC478 enhances the oral bioavailability of docetaxel in vitro and in vivo. LC478 inhibited P-gp mediated efflux of docetaxel in Caco-2 cells. In addition, $100 \mathrm{mg} / \mathrm{kg}$ of LC478 increased intestinal absorption of docetaxel, which led to an increase in area under plasma concentration-time curve $(A U C)$ and absolute bioavailability of docetaxel in rats. According to U.S. FDA criteria ( $I$, an inhibitor concentration in vivo tissue $) /\left(I C_{50}\right.$, inhibitory constant in vitro $)>10$ determines P-gp inhibition between in vitro and in vivo. The values 15.6-20.5, from (LC478 concentration in intestine, 9.37-12.3 $\mu \mathrm{M}) /\left(\mathrm{IC}_{50}\right.$ of LC478 on P-gp inhibition in Caco-2 cell, $0.601 \mu \mathrm{M}$ ) suggested that $100 \mathrm{mg} / \mathrm{kg}$ of LC478 sufficiently inhibited P-gp to enhance oral absorption of docetaxel. Moreover, LC478 inhibited P-gp mediated efflux of docetaxel in the ussing chamber studies using rat small intestines. Our study demonstrated that the feasibility of LC478 as an ideal enhancer of docetaxel bioavailability by P-gp inhibition in dose (concentration)-dependent manners.
\end{abstract}

Keywords: docetaxel; bioavailability; absorption; LC478; P-glycoprotein; inhibition

\section{Introduction}

Docetaxel, a second-generation taxane, has significant and broad anti-tumor activities against breast, ovary, prostate, non-small cell lung, and gastric cancers [1,2]. An intravenous formulation of docetaxel that is currently marketed (Taxotere ${ }^{\circledR}$, Sanofi SA, Paris, France) shows several drawbacks including non-ionic surfactant-induced severe hypersensitivity reaction [3], skin damage, extravasation catheter-related infection, and potential thrombosis by intravenous injection [4,5]. Oral docetaxel chemotherapy is a desired alternative regimen [5,6] in terms of administration convenience, better patient compliance, and prolonged systemic exposure profile with less fluctuation [7-9]. Nevertheless, the low oral bioavailability of docetaxel (less than $5 \%$ of the oral dose) impedes its clinical application of oral chemotherapy owing to its physiochemical properties (e.g., low water solubility and membrane permeability) and its physiological barriers (e.g., pre-systemic metabolism via cytochrome P450 (CYP)3A and transmembrane efflux via P-glycoprotein (P-gp)) [2,5,10-15].

In pharmacokinetic characteristics of docetaxel, docetaxel is metabolized via CYP3A isoforms and the predominant elimination of docetaxel and its metabolites are biliary and intestinal excretion as systemic clearance pathways of docetaxel [16,17]. In addition, ATP-binding cassette (ABC) transporters (e.g., P-gp, multidrug resistance-associated protein 1 (MRP1), MRP2 and breast cancer resistance protein (BCRP) transporters) in enterocytes or hepatocytes and human solute carrier (SLC) transporters 
(e.g., organic anion transporting polypeptides (OATP)1B1 and 1B3) in hepatocytes can modulate docetaxel disposition [18-21].

In tackling the hurdles of a low bioavailability of docetaxel, P-gP (MDR1 or ABCB1) has gained attention. P-gp has been identified to regulate absorption, distribution, and/or excretion of a broad range of more than 300 compounds [22-24]. P-gp is highly expressed in tumor cells and normal tissues including intestines, liver, kidney, blood brain barrier, testes, and placenta [22,23]. In particular, P-gp-mediated efflux of its substrate drug from the gut wall into the intestinal lumen hampers oral absorption [25]. At this point, inhibiting P-gp can increase systemic exposure and subsequent pharmacological efficacy in target tissues of its substrate drug [25,26]. Numerous efforts to overcome low oral bioavailability of docetaxel with P-gp inhibitors (e.g., verapamil, cyclosporine, ketoconazole, and quinidine for first-generation; R-verapamil, valspodar, and viridodar for second-generation; and elacridar, zosuquidar, and ONT-093 for third-generation) have been undertaken $[2,10,11,19,20,27,28]$. Especially, in the development of third generation of P-gp inhibitors, their own pharmacological activities, intrinsic toxicities, non-selectivity, and unexpected pharmacokinetic interactions (e.g., reduction of CYP3A-mediated metabolic activities) of P-gp inhibitors have overcome and they showed sufficient efficacy as P-gp inhibitor in vitro and in vivo $[19,20,29-32]$. Thus, the maintenance of sufficient concentration to inhibit P-gp function in the intestine in tandem with non-toxic concentration in other tissues is required for P-gp inhibitor candidates to enhance docetaxel bioavailability.

Min et al. [33] reported that LC478 (Figure 1), one of di-substituted adamantyl derivatives synthesized, reversed P-gp mediated efflux activity of palictaxel in P-gp overexpressing MES-SA/DX5 sarcoma cells without intrinsic cytotoxicity. Therefore, we investigated the potential of LC478 for enhancing the oral bioavailability of docetaxel by P-gp inhibition in vitro and in vivo.

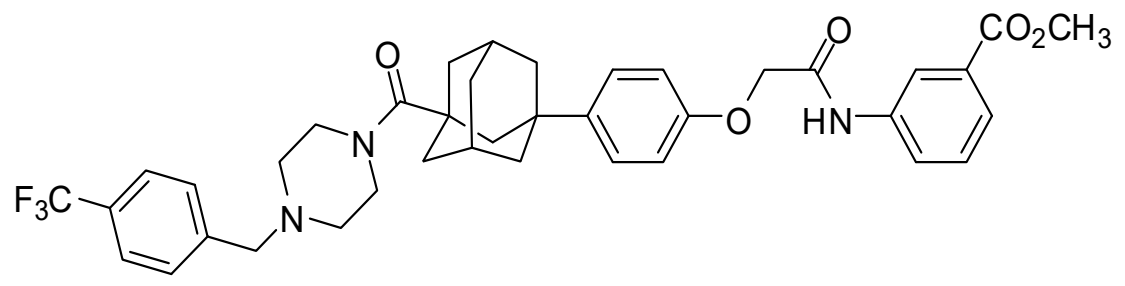

Figure 1. Structure of LC478.

\section{Materials and Methods}

\subsection{Chemicals}

LC478 (Figure 1) was prepared following the previously reported procedure [33]. Shin Poong Pharmaceutical Company, Ltd. (Ansan, Korea) supplied the docetaxel trihydrate. Paclitaxel (internal standard for docetaxel analysis using liquid chromatographic tandem mass spectrometry (LC-MS/MS)), dextran (MW 65,000), the reduced form of $\beta$-nicotinamide adenine dinucleotide phosphate, NADPH as a tetrasodium salt), tri(hydroxymethyl)aminomethane(tris)-buffer, 3-(4,5-dimethylthiazol-2-yl)-2,5-diphenyltetrazolium bromide (MTT), verapamil, and rhodamine-123 were purchased from Sigma-Aldrich Korea (St. Louis, MO, USA). Other chemicals and reagents were high-performance liquid-chromatography (HPLC) grades.

\subsection{Cell Culture and Cell Viability Assay}

Caco-2 cells were obtained from the Korean Cell Line Bank (Seoul, Korea). The cells were maintained in Dulbecco's modified Eagle's medium (DMEM) supplemented with $10 \%$ fetal bovine serum, $1 \%$ non-essential amino acids, and $100 \mathrm{U} / \mathrm{mL}$ penicillin and gentamicin at $37^{\circ} \mathrm{C}$ in a humidified $5 \% \mathrm{CO}_{2}$ atmosphere [34]. 
The effect of LC478 on cell viability was assessed by an MTT assay. LC478 was dissolved in diluted in 100\% dimethyl sulfoxide (DMSO) and diluted with cell culture media. Caco-2 cells were seeded in 96-well plates at $1 \times 10^{5}$ cells $/ \mathrm{mL}$. A $100 \mu \mathrm{L}$ of LC478 in cell culture media was treated on the plates to achieve final concentration of LC478 in the ranges of 0.001 to $100 \mu \mathrm{M}$, which was incubated for $24 \mathrm{~h}$. After adding $10 \mu \mathrm{L} /$ well of MTT $(5 \mathrm{mg} / \mathrm{L})$ and incubating them for $24 \mathrm{~h}$, the supernatants of the cultures were removed and replaced with $100 \mu \mathrm{L}$ of DMSO. The cell viability rate (\%) was calculated as the absorbance of treated cells divided by that of control cells. The viability of the control cells was defined as $100 \%$.

\subsection{Effect of LC478 on P-gp Mediated Efflux of Rhodamine-123, a P-gp Substate, in Caco-2 Cells}

To investigate the effect of LC478 on P-gp activity, the transcellular transport activity of rhodamine-123 across the Caco-2 cells was performed with modification of the previous reports [35-38]. Rhodamine-123 and verapamil were used as a typical P-gp substrate and inhibitor, respectively. Caco-2 cell was seeded at a surface density of $160,000 \mathrm{cells} / \mathrm{cm}^{2}$ on polycarbonate microporous membrane inserts in 12-well Transwell plates. They were allowed to grow to confluence for 5 days to obtain higher expressions of P-gp. The transcellular transport activities of doectaxel in Caco-2 monolayers were measured when transepithelial electrical resistance (TEER) values were higher than $>200 \Omega \cdot \mathrm{cm}^{2}$. Briefly, both apical (A) and the basolateral (B) chambers of each insert were washed twice with $37^{\circ} \mathrm{C}$ in Hank's balanced salt solution (HBSS) buffer with $\mathrm{pH}$ 7.4, and were pre-incubated for $30 \mathrm{~min}$. The assay was initiated by replacement of buffer at either the A $(0.5 \mathrm{~mL})$ or B side $(1.5 \mathrm{~mL})$ containing rhodamine-123 $(1 \mu \mathrm{M})$ with vehicle, LC478 $(1$ and $10 \mu \mathrm{M})$ or verapamil $(10 \mu \mathrm{M})$, respectively. At 30, 60, 90,120 , and $150 \mathrm{~min}$, a $200 \mu \mathrm{L}$ buffer was removed from the receiver compartment and replaced with the same volume of $\mathrm{HBSS}$ solution at $37^{\circ} \mathrm{C}$. All samples were stored at $-80^{\circ} \mathrm{C}$ until the determination of rhodamine-123 using LC-MS/MS analytical method [39].

In addition, effect of LC478 on intracellular accumulations of rhodamine- 123 in Caco- 2 cells was evaluated by following the modification of the previous reported method [40]. Fifty thousand Caco-2 cells were seeded in 48-well plates and they were allowed to grow to confluence for 5 days to obtain higher expressions of P-gp. When the cells reached to $90 \%$ confluency, $200 \mu \mathrm{L}$ of vehicle, verapamil (0.001-100 $\mu \mathrm{M})$ or LC478 $(0.001-100 \mu \mathrm{M})$ was added per well, respectively. After $24 \mathrm{~h}$ pre-treatment of verapamil or LC78, cells were washed with phosphate buffer saline (PBS) and $200 \mu \mathrm{L}$ of $10 \mu \mathrm{M}$ rhodamine-123 diluted in HBSS with 10 mM HEPES (pH 7.4) was added to each well. After $2 \mathrm{~h}$ incubation, the uptake was stopped by aspirating the rhodamine-123/HBSS solution and washing the cells 3 times with ice-cold PBS. Subsequently, cells were lysed with $200 \mu \mathrm{L}$ of $0.1 \%$ Triton X-100 for $30 \mathrm{~min}$ at room temperature and $100 \mu \mathrm{L}$ aliquots were used to measure rhodamine-123 using the LC-MS/MS analytical method [39]. The half-maximal inhibitory constant $\left(I C_{50}\right)$ values of LC478 or verapamil for inhibition of P-gp activity are corresponded to the half-maximal effective constant $\left(\mathrm{EC}_{50}\right)$ for increasing rhodamine-123 accumulation. Data are expressed as a \% of rhodamine-123 concentration in control Caco-2 cells (exposed to vehicle), arbitrarily at 100\% and are the means of standard error of the mean (SEM) of three independent experiments.

\subsection{Effect of LC478 on P-gp Mediated Efflux of Docetaxel in Caco-2 Cells}

To evaluate the effect of LC478 on P-gp mediated efflux of docetaxel in Caco-2 cells, IC $_{50}$ values of LC478 on inhibition of intracellular accumulations of docetaxel were calculated by the same methods in Section 2.3. Instead of rhodamine-123, docetaxel was adjusted.

\subsection{Animals}

Male Sprague-Dawley rats at 6-9 weeks old (weighing 200-260 g) were purchased from Charles River Company Korea (Orient, Seoul, Korea). The institute of Laboratory Animal Resources of Dongguk University_Seoul (Seoul, Korea) reviewed and approved the experimental protocols 
involving animals in this study (approval no. IACUC-2015-044, 12 September 2015). All rats were maintained in the same conditions as a reported method [35,37].

\subsection{Pharmacokinetic Studies of Docetaxel with LC478}

Early in the morning, rats were anesthetized by intramuscular injection of $125 \mathrm{mg}(1.5 \mathrm{~mL}) / \mathrm{kg}$ of tiletamine $\mathrm{HCl}$ and zolazepam $\mathrm{HCl}$ mixture. The surgical procedures including cannulating the carotid artery (for blood sampling) and/or the jugular vein (only for intravenous drug administration) using PE50 tubes were conducted under light ether anesthesia and rats were allowed for $4-5 \mathrm{~h}$ to recover from the anesthesia before the study began similar to a previously reported method [35].

For the intravenous study, rats were divided into three groups according to LC478 doses $(0,30$, and $100 \mathrm{mg} / \mathrm{kg}$ LC478, respectively). Two hours before docetaxel administration, oral administration of 0, 30, or $100 \mathrm{mg}(5 \mathrm{~mL}) / \mathrm{kg}$ LC478 (dissolved in the polyethylene glycol 400 (PEG400): Distilled water $=1: 1, v / v)$ was performed in rats. After $2 \mathrm{~h}, 20 \mathrm{mg}(2 \mathrm{~mL}) / \mathrm{kg}$ of docetaxel (docetaxel trihydrate dissolved in dimethylacetamide (DMA): Distilled water $=4: 6, v / v$ ) was administered intravenously to the rats. Blood samples (approximately $0.22 \mathrm{~mL}$, each) were withdrawn from the carotid artery at 0 (control), 1 (end of the docetaxel infusion), 5, 15, 30, 60, 90, 120, 180, 240, 300, and $360 \mathrm{~min}$ after docetaxel administration. To prevent blood clotting, $0.3 \mathrm{~mL}$ of $0.9 \% \mathrm{NaCl}$-injectable solution containing heparin $(20 \mathrm{U} / \mathrm{mL})$ was flushed into each cannula immediately after each blood sampling. After the blood sample was centrifuged, a $100 \mu \mathrm{L}$ aliquot of plasma was stored at $-70^{\circ} \mathrm{C}$ (Revco ULT $1490 \mathrm{D}-\mathrm{N}-\mathrm{S}$; Western Mednics, Asheville, NC, USA). The $24 \mathrm{~h}$ urine and gastrointestinal tract (its entire contents including feces) samples were prepared and handled following a previously reported method [35]. At $24 \mathrm{~h}$, distilled water $(10 \mathrm{~mL})$ was gently flushed into each metabolic cage and the resulting fluid combined with the urine was collected over the previous $24 \mathrm{~h}$. At this time, each rat was sacrificed by withdrawing blood via a heart puncture, and then the entire gastrointestinal tract (including its contents and feces) was extracted and transferred into a beaker. After adding $100 \mathrm{~mL}$ of methanol (to facilitate the extraction of docetaxel) into each beaker, the gastrointestinal tract samples in methanol were cut into small pieces and manually stirred. A $100 \mu \mathrm{L}$ aliquot of the supernatant was collected from each beaker.

For the oral study, after overnight fasting with free access to water, rats were divided into three subgroups according to the doses of LC478 administered, which were the same as in the intravenous study. After $2 \mathrm{~h}, 20 \mathrm{mg}(5 \mathrm{~mL}) / \mathrm{kg}$ of docetaxel (the same solution used in the intravenous study) was orally administered to the rats using a gastric gavage tube. Blood samples were withdrawn from the carotid artery at $0,5,15,30,60,90,120,180,240,300$, and $360 \mathrm{~min}$ after oral administration of docetaxel. Other procedures were followed to the intravenous study.

Based on the standard methods [41-44], we calculated the following pharmacokinetic parameters using non-compartmental analysis (WinNonlin ${ }^{\circledR}$; Professional Edition version 2.1; Pharsight, Mountain View, CA, USA): The total area under the plasma concentration-time curve from time zero to last blood sampling time $\left(A U C_{\text {last }}\right)$ or time infinity $\left(A U C_{\text {inf }}\right)$ by log-linear trapezoidal extrapolation method [37], terminal half-life, time-averaged total body, renal, and non-renal clearances $\left(C L, C L_{R}\right.$, and $C L_{N R}$, respectively), mean residence time $(M R T)$, apparent volume of distribution at a steady state $\left(V_{\mathrm{ss}}\right)$, apparent oral clearance $(C L / F)$, and apparent volume of distribution during elimination $\left(V_{\mathrm{z}} / F\right)$. We directly read the peak plasma concentration $\left(C_{\max }\right)$ and time to reach $C_{\max }\left(T_{\max }\right)$ from the experimental data. The percentage of the dose excreted into urine up to $24 \mathrm{~h}\left(A e_{0-24 \mathrm{~h}}\right)$ and the percentage of the dose recovered from the gastrointestinal tract (including its contents and feces) at $24 \mathrm{~h}\left(G_{24} \mathrm{~h}\right)$ were calculated from concentrations of docetaxel in $24 \mathrm{~h}$ urine and gastrointestinal tract samples versus the administered dose of docetaxel, respectively [37]. 
The absorbed fraction of oral dose $\left(F_{\text {abs }}\right)$ [45], absolute bioavailability $(F)$, and relative bioavailability $\left(F_{\text {rel }}\right)$ were calculated by the following equations.

$$
\begin{gathered}
F(\%)=\frac{A U C_{\text {inf, p.o }}}{A U C_{\text {inf, i.v }}} \times 100 \\
F_{\text {rel }}(\%)=\frac{A U C_{\text {inf }} \text { with LC } 478}{A U C_{\text {inf }} \text { without LC } 478} \times 100 \\
\frac{G I_{24 \text { h, p.o }}}{100}=\left(1-F_{\text {abs }}\right)+\left(\frac{F}{100} \times \frac{G I_{24} \text { h, i.v. }}{100}\right)
\end{gathered}
$$

The "i.v." and "p.o." represented intravenous and oral administration, respectively.

\subsection{Effects of LC478 on Bi-Directional Transport of Rhodamine-123 or Docetaxel Across Rat Duodenum Using the Ussing Chamber}

To evaluate the effect of LC478 on P-gp mediated efflux activity in rat's small intestine, transport experiments were conducted following the previously reported method [37,46,47]. The incubation medium (pH 7.4) involving $1.2 \mathrm{mM} \mathrm{NaCl}, 5 \mathrm{mM} \mathrm{KCl}, 1.2 \mathrm{mM} \mathrm{CaCl}_{2}, 1.2 \mathrm{mM} \mathrm{MgCl}_{2}, 25 \mathrm{mM} \mathrm{NaHCO}_{3}$, $1.6 \mathrm{mM} \mathrm{Na}_{2} \mathrm{HPO}_{4}, 0.4 \mathrm{mM} \mathrm{NaH}_{2} \mathrm{PO}_{4}, 5 \mathrm{mM}$ D-glucose, and $5 \mathrm{mM}$ D-mannitol was used throughout the transport experiments. After blood sampling was conducted by heart puncture under the light anesthetic condition by a mixture of $125 \mathrm{mg} / \mathrm{kg}$ of tiletamine $\mathrm{HCl}$ and zolazepam $\mathrm{HCl}$, each control rat was sacrificed by cervical dislocation. The small intestine ( $2 \mathrm{~cm}$ from the proximal part of jejunum) was removed, opened along the mesenteric border and rinsed immediately in ice-cold buffer ( $\mathrm{pH}$ 7.4) under carbogen $\mathrm{O}_{2} / \mathrm{CO}_{2}(95 \% / 5 \%)$ bubbling. The specimens were fixed to $0.61 \mathrm{~cm}^{2}$ surface area of cells in the Ussing chambers without harming the underlying muscle layer and formed two compartments, mucosal (M) and serosal (S) chambers. One milliliter of incubation medium was spiked into each chamber at $37{ }^{\circ} \mathrm{C}$ with continuous oxygenation and carbogen $\mathrm{O}_{2} / \mathrm{CO}_{2}(95 \% / 5 \%)$ bubbling through each compartment for oxygenation and agitation. Then, $5 \mu \mathrm{L}$ of verapamil (at a final concentration of $10 \mu \mathrm{M}$ ), LC478 (at a final concentration of 0,1 , or $10 \mu \mathrm{M}$ ) or incubation medium (control) was added to both sides of the chamber. After $30 \mathrm{~min}$ of pre-incubation time before the experiments began, rhodamine-123 (at a final concentration of $10 \mu \mathrm{M}$ ) was added to the apical compartment for absorptive ( $\mathrm{M}$ to $\mathrm{S}$ ) transport or to the basolateral compartment for secretory (S to $\mathrm{M}$ ) transport. During the $3 \mathrm{~h}$ for the transporter experiment, each $50 \mu \mathrm{L}$ sample was withdrawn from the acceptor chamber at half-hour intervals and immediately replaced with $50 \mu \mathrm{L}$ of incubation medium. The concentration of rhodamine-123 in each sample was determined by HPLC analysis [39]. Cumulative corrections were made for previously removed samples and apparent permeability coefficients $\left(P_{\text {app }}, \mathrm{cm} / \mathrm{s}\right)$ were calculated as follows: $P_{\text {app }}=Q / A \cdot c \cdot t$, where $Q$ is the total amount of the drug permeated throughout the incubation time, $A$ is the diffusion area of the Ussing chamber, $c$ is the initial drug concentration in the donor compartment, and $t$ is the total time of the experiment. Efflux ratios were calculated from $P_{\text {app }}$ values by: Efflux ratio $=$ secretory $P_{\text {app }} /$ absorptive $P_{\text {app }}$.

To evaluate the effect of LC478 on the transepithelial transport of docetaxel, the same experiment was performed using docetaxel $(1 \mu \mathrm{M})$ instead of rhodamine- 123 .

\subsection{Effect of LC478 for Disappearance of Docetaxel in Rat Hepatic and Intestinal Microsomes}

We investigated the inhibitory mode for the metabolism of docetaxel by LC478 based on a previously reported method [37]. The hepatic and intestinal microsomes were prepared based on a similar reported method [37].

The following constituents were added to a tube: Hepatic ( $1 \mathrm{mg}$ protein) or intestinal $(0.3 \mathrm{mg}$ protein) microsome; $2.5 \mu \mathrm{L}$ of methanol containing $0.2,1,5,20,50$, and $100 \mu \mathrm{M}$ docetaxel (a substrate) as final concentrations; $2.5 \mu \mathrm{L}$ of methanol containing $0,1,5$, and $10 \mu \mathrm{M} \mathrm{LC} 478$ (an inhibitor) as final concentrations and $50 \mu \mathrm{L}$ of $1 \mathrm{mM}$ of NADPH dissolved in $0.1 \mathrm{M}$ phosphate buffer of $\mathrm{pH}$ 7.4. Adding 
$0.1 \mathrm{M}$ phosphate buffer ( $\mathrm{pH}$ 7.4) adjusted the total volume as $0.5 \mathrm{~mL}$, and then the components were incubated at $37^{\circ} \mathrm{C}$ using a thermomixer at $500 \mathrm{opm}$. After incubation of 15 and $30 \mathrm{~min}$ for the hepatic and intestinal microsomes, respectively, $1 \mathrm{~mL}$ of acetonitrile with $5 \mu \mathrm{g} / \mathrm{mL}$ of paclitaxel as an internal standard added to terminate the reaction. We determined the concentration of docetaxel in each sample by LC-MS/MS analysis [37].

We calculated the kinetic constants $\left(K_{\mathrm{m}}\right.$ and $\left.V_{\max }\right)$ for the docetaxel disappearance using non-linear regression [48] using Sigma plot 10.0 (Systat Software, San Jose, CA, USA). The unweighted kinetic data from rat hepatic and intestinal microsomes were fitted using a single-site Michaelis-Menten Equation

$$
V=V_{\max } \times[\mathrm{S}] /\left(K_{\mathrm{m}}+[\mathrm{S}]\right)
$$

where [S] is the substrate concentration, $V_{\max }$ is maximal velocity, and $K_{\mathrm{m}}$ is substrate concentration for half-maximal velocity. The $C L_{\text {int }}$ was calculated by dividing the $V_{\max }$ by the $K_{\mathrm{m}}$.

\subsection{Effect of LC478 on Rat Plasma Protein Binding of Docetaxel with LC478}

Using equilibrium dialysis [37], protein binding values of docetaxel with and without LC478 were measured in fresh plasma from control rats $(n=5$; each). A $1 \mathrm{~mL}$ of the plasma was dialyzed against $1 \mathrm{~mL}$ of isotonic Sørensen phosphate buffer ( $\mathrm{pH} 7.4)$ containing 3\% dextran $(w / v)$ in a dialysis cell (Spectrum Medical Industries, Laguna Hills, CA, USA) using a Spectra/Por 4 membrane (mol. wt. cutoff 12-14 KDa; Spectrum Medical Industries, USA). After $24 \mathrm{~h}$ incubation, $50 \mu \mathrm{L}$ was collected from each compartment and determined using LC-MS/MS analysis of docetaxel [37].

\subsection{Analytical Methods of Docetaxel and LC478}

Concentrations of docetaxel in the samples were determined with a slight modification to the previously reported LC-MS/MS analysis [37]. A $100 \mu \mathrm{L}$ of a biological sample was deproteinized with $200 \mu \mathrm{L}$ of acetonitrile containing $25 \mathrm{ng} / \mathrm{mL}$ of paclitaxel (internal standard). After vortex-mixing and centrifugation of the above mixture, $10 \mu \mathrm{L}$ of the supernatant was directly loaded onto a $\mathrm{C}_{18}$ column (Symmetry BEH phenyl; $100 \mathrm{~mm} . \ell$. $\times 2.1 \mathrm{~mm}$. i.d.; particle size, $3.4 \mu \mathrm{m}$; Waters, Milford, MA, USA). The mobile phase consisted of $0.1 \%$ formic acid and acetonitrile $(50: 50, v / v)$, which was run at a flow-rate of $0.3 \mathrm{~mL} / \mathrm{min}$. The API 4000 triple quadrupole mass spectrometer (ABI/MDS sciex model, Framingham, MA, USA) operated in positive multiple reaction monitoring mode at $50 \mathrm{~L} / \mathrm{min}$ of nebulizing gas flow, $50 \mathrm{~L} / \mathrm{min}$ of the auxiliary gas flow, $50 \mathrm{~L} / \mathrm{min}$ of CAD gas flow and $20 \mathrm{~L} / \mathrm{min}$ of curtain gas flow. The source temperature was set at $250{ }^{\circ} \mathrm{C}$ and the ion spray voltage was $5500 \mathrm{~V}$. The MS/MS transitions of docetaxel and paclitaxel were $m / z[\mathrm{M}+\mathrm{H}]^{+} 808.5 \rightarrow 527.1$ and $m / z[\mathrm{M}+\mathrm{H}]^{+}$ $854.3 \rightarrow 286.2$, respectively. The detection limits of docetaxel were $0.1 \mathrm{ng} / \mathrm{mL}$ in biological samples with a signal to noise ratio of 3 .

Concentration of LC478 was determined using a HPLC-UV system. A $50 \mu \mathrm{L}$ aliquot of acetonitrile was added to a $50 \mu \mathrm{L}$ aliquot of biological sample. After vortex-mixing and centrifugation, the supernatant was evaporated (Dry Thermo Bath MG-2200, Eyela, Tokyo, Japan) under a soft stream of nitrogen gas at $50{ }^{\circ} \mathrm{C}$. The residue was reconstituted in $60 \mu \mathrm{L}$ mobile phase and a $50 \mu \mathrm{L}$ aliquot of the supernatant was loaded onto a reverse-phase $C_{18}$ column (SunFireTM; $150 \mathrm{~mm} . \ell . \times 4.6 \mathrm{~mm}$. i.d.; particle size, $5 \mu \mathrm{m}$; Waters, Milford, MA, USA). The mobile phase was organic solvent consisting acetonitrile: Methanol at a ratio of $25: 45(\mathrm{v} / \mathrm{v})$ with $0.3 \%$ formic acid, and the flow rate was $1.7 \mathrm{~mL} / \mathrm{min}$. The column eluent was monitored at $256 \mathrm{~nm}$. The retention time of LC478 was approximately $7.8 \mathrm{~min}$, and the quantitation limit was $0.1 \mu \mathrm{g} / \mathrm{mL}$.

\subsection{Statistical Analysis}

When it was necessary to compare the means among the three means for the unpaired data, a Duncan's multiple range test in conjunction with posteriori analysis of variance (ANOVA) in Social 
Package of Statistical Sciences (SPSS) was typically used. Statistical significance was considered as a $p$ value of $<0.05$.

\section{Results}

\subsection{Effect of LC478 on Cace-2 Cell Viability}

The effect of LC478 on Caco-2 cell viability was evaluated using an MTT assay. Caco-2 cell was cultured with different concentrations of LC478 from 0.001 to $100 \mu \mathrm{M}$ for $24 \mathrm{~h}$ and the cell viability was 97-100\%. Results showed that LC478 was not toxic to Caco-2 cells even at $100 \mu \mathrm{M}$ for $24 \mathrm{~h}$ incubation.

\subsection{Effect of LC478 on P-gp Mediated Efflux of Rhodamine-123, a P-gp Substate, in Caco-2 Cells}

To examine the effect of LC478 on P-gp activity, rhodamine-123 transmembrane efflux was conducted in Caco- 2 cells. First, transmembrane efflux of rhodamine- 123 in Caco- 2 cells was evaluated in the presence of LC478 $(1$ or $10 \mu \mathrm{M})$ or verapamil $(10 \mu \mathrm{M})$, a representative P-gp inhibitor (Figure 2A and Table 1). Verapamil $(10 \mu \mathrm{M})$, a positive control, efficiently inhibited P-gp mediated efflux of rhodamine-123 represented by secretory $P_{\text {app }}$ values, and its activity was decreased to $136 \%$ of the control. LC478 also exhibited the significant inhibitory effects ( $45.3 \%$ decrease by $1 \mu \mathrm{M}$ LC478 and $169 \%$ decrease by $10 \mu \mathrm{M}$ LC478, respectively) based on secretory $P_{\text {app }}$ values, indicating that LC478 concentration dependently inhibited P-gp mediated efflux activity. Efflux ratios of LC478 $(10 \mu \mathrm{M})$ and verapamil $(10 \mu \mathrm{M})$ were 0.349 - and 0.362 -fold lower than that of control, respectively. However, there was no changes of absorptive $P_{\text {app }}$ values among all groups.

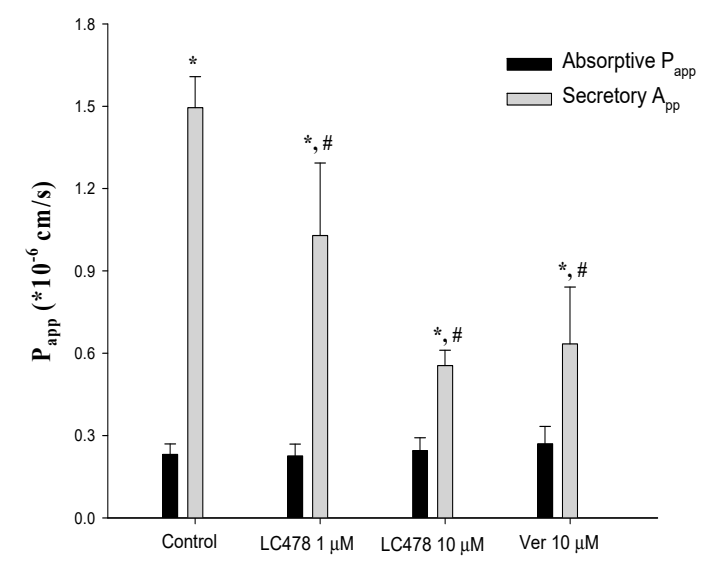

(A)
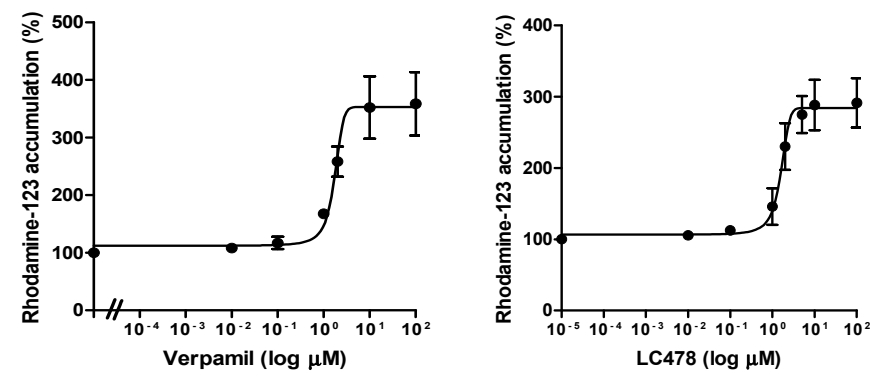

(B)

Figure 2. Effect of LC478 on P-gp mediated efflux of rhodamine-123. (A) Absorptive $P_{\text {app }}(\mathbf{\square})$ and secretory $P_{\text {app }}(\mathbf{\square})$ of rhodamine-123 with LC478 $(1$ and $10 \mu \mathrm{M})$ or verapamil $(10 \mu \mathrm{M})$ across Caco-2 cells. Vertical bars represent standard deviation (SD) and the number of each group is three. * Significantly different $(p<0.05)$ from absorptive $(\mathrm{M}$ to $\mathrm{S})$ group. \# Significantly different $(p<0.05)$ from the control group. (B) The $E C_{50}$ curves of verapamil (left) and LC478 (right) on rhodamine-123 accumulation in Caco-2 cells. Vertical bar represents standard error of the mean (SEM) and number of each group is three. 
Table 1. Absorptive $P_{\text {app }}$, secretory $P_{\text {app }}$, efflux ratio of rhodamine- 123 in Caco- 2 cells with various concentrations of LC478 or verapamil.

\begin{tabular}{lccc}
\hline \multirow{2}{*}{ Compounds } & \multicolumn{2}{c}{$\boldsymbol{P}_{\text {app }}\left(\times \mathbf{1 0}^{-\mathbf{6}} \mathbf{c m} / \mathbf{s}\right)$} & \multirow{2}{*}{ Efflux Ratio } \\
\cline { 2 - 3 } & Absorptive (A to B) $\boldsymbol{n}=\mathbf{3}$ & Secretory (B to A) $\boldsymbol{n = 3}$ & \\
\hline Control & $0.231 \pm 0.0388$ & $1.50 \pm 0.113^{\mathrm{a}}$ & 6.49 \\
$1 \mu$ M LC478 & $0.226 \pm 0.0429$ & $1.03 \pm 0.264^{\mathrm{a}, \mathrm{b}}$ & 4.56 \\
$10 \mu$ M LC478 & $0.245 \pm 0.0469$ & $0.555 \pm 0.0564^{\mathrm{a}, \mathrm{b}}$ & 2.27 \\
$10 \mu$ M Verapamil & $0.270 \pm 0.0634$ & $0.634 \pm 0.207^{\mathrm{a}, \mathrm{b}}$ & 2.35 \\
\hline
\end{tabular}

Data are the mean \pm SD. $P_{\text {app }}$, permeability coefficient; efflux ratio, the ratio of secretory $P_{\text {app }}$ to absorptive $P_{\text {app }}$. a Significantly different $(p<0.05)$ from absorptive (A to B) group. ${ }^{b}$ Significantly different $(p<0.05)$ from the control group.

In addition, the half-maximal inhibitory constant $\left(I_{50}\right)$ values of verapamil or LC478 for inhibition of P-gp activity were estimated corresponding to their half-maximal effective constant $\left(E C_{50}\right)$ values for increasing rhodamine-123 accumulation. The $E C_{50}$ curves of verapamil and LC478 for percentage of rhodamine-123 accumulation in Caco-2 cells were shown in Figure $2 \mathrm{~B}$. The $I C_{50}$ values of verapamil and LC478 for P-gp activity were $2.874 \pm 0.432$ and $1.674 \pm 0.404 \mu \mathrm{M}$ in Caco-2 cells, based on their respective $\mathrm{EC}_{50}$ value for increasing rhodamine accumulation in Caco-2 cells.

\subsection{Effect of LC478 on P-gp Mediated Efflux of Docetaxel in Caco-2 Cells}

To determine the effect of LC478 on P-gp mediated efflux of docetaxel in Caco-2 cells, the $I_{50}$ value of LC478 on P-gp mediated efflux of docetaxel was estimated from $E C_{50}$ value of LC478 for increasing docetaxel accumulation in Caco-2 cells. The $E C_{50}$ curves of $\mathrm{LC} 478$ for percentage of docetaxel accumulation in Caco-2 cells were shown in Figure 3. The IC $C_{50}$ of LC478 for the P-gp activity were $0.601 \pm 0.115 \mu \mathrm{M}$ in Caco-2 cells based on its $E C_{50}$ value for increasing docetaxel accumulation in Caco-2 cells.

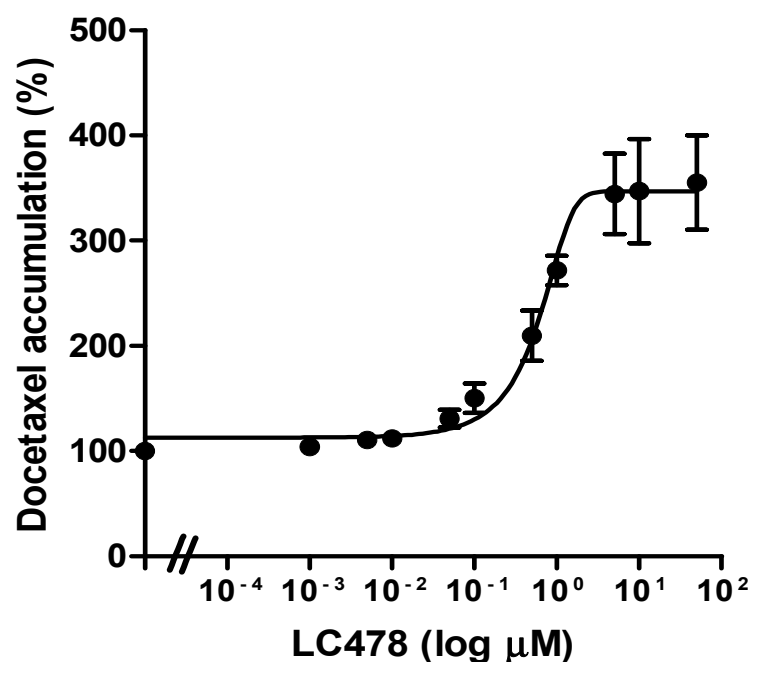

Figure 3. Effect of LC478 on P-gp activity. The $E C_{50}$ curves of LC478 on docetaxel accumulation in Caco-2 cells. The vertical bar represents SEM and the number of each group is three.

\subsection{Effect of LC478 on Pharmacokinetics of Docetaxel}

The mean arterial plasma concentration-time profiles of docetaxel after intravenous and oral administration of docetaxel with oral LC478 $(0,30$ or $100 \mathrm{mg} / \mathrm{kg})$ to rats are shown in Figure 4 . The relevant pharmacokinetic parameters are also summarized in Table 2. After intravenous administration of docetaxel with 30 or $100 \mathrm{mg} / \mathrm{kg}$ LC478, pharmacokinetic parameters of docetaxel (except $C L_{\mathrm{R}}$ and $A e_{0-24 \mathrm{~h}}$ ) did not differ from those without LC478. The $C L_{\mathrm{R}}$ of docetaxel with $100 \mathrm{mg} / \mathrm{kg}$ LC478 was significantly slower (by $40 \%$ ) than that without LC478. In addition, $A e_{0-24 \mathrm{~h}}$ of 
docetaxel with $100 \mathrm{mg} / \mathrm{kg}$ LC478 was significantly smaller (by $31.1 \%$ and $37.2 \%$ ) than that with 0 and $30 \mathrm{mg} / \mathrm{kg}$ LC478, respectively.
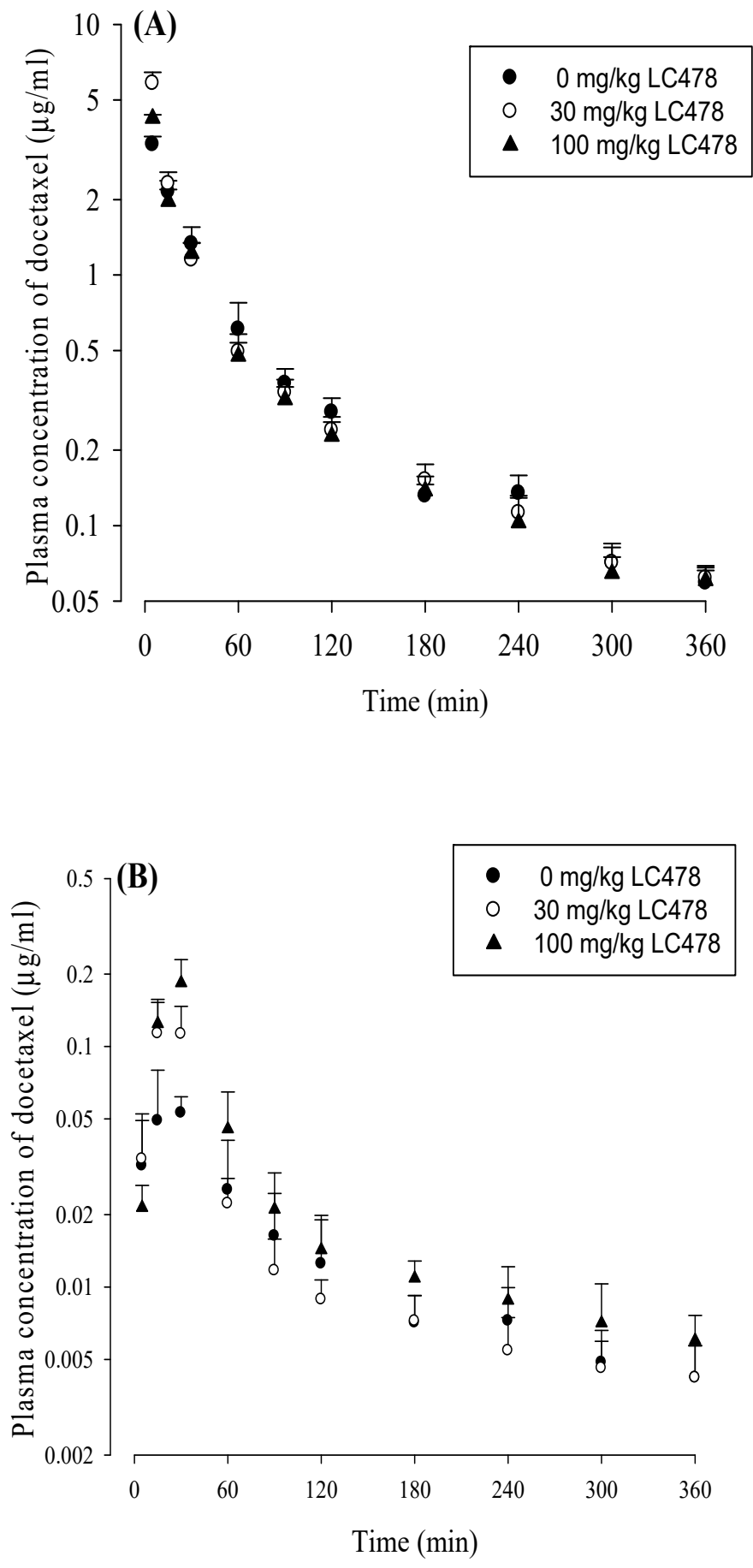

Figure 4. (A) Mean arterial plasma concentration-time profiles of docetaxel after its intravenous administration with $0(\bigcirc ; n=6), 30(\bullet ; n=6)$ or $100(\mathbf{\Lambda} ; n=6) \mathrm{mg} / \mathrm{kg}$ LC478 in rats. (B) Mean arterial plasma concentration-time profiles of docetaxel after its oral administration with $0(\bigcirc ; n=5), 30(\bullet$; $n=6)$, and $100(\boldsymbol{\Lambda} ; n=6) \mathrm{mg} / \mathrm{kg} \mathrm{LC} 478$ in rats. Vertical bar represents SD. 
Table 2. Pharmacokinetic parameters of docetaxel after intravenous and oral administration of docetaxel $(20 \mathrm{mg} / \mathrm{kg})$ with 0,30 , or $100 \mathrm{mg} / \mathrm{kg}$ of LC478 in rats.

\begin{tabular}{|c|c|c|c|}
\hline Parameter & $0 \mathrm{mg} / \mathrm{kg}$ & $30 \mathrm{mg} / \mathrm{kg}$ & $100 \mathrm{mg} / \mathrm{kg}$ \\
\hline Intravenous Study & $n=6$ & $n=6$ & $n=6$ \\
\hline Body weight (g) & $302 \pm 7.45$ & $296 \pm 4.49$ & $301 \pm 18.8$ \\
\hline$A U C_{\text {last }}(\mu \mathrm{g} \min / \mathrm{mL})$ & $253 \pm 38.1$ & $290 \pm 46.6$ & $268 \pm 39.2$ \\
\hline$A U C_{\text {inf }}(\mu \mathrm{g} \min / \mathrm{mL})$ & $265 \pm 39.0$ & $303 \pm 46.5$ & $275 \pm 40.2$ \\
\hline Terminal half-life (min) & $122 \pm 36.6$ & $144 \pm 37.6$ & $151 \pm 34.5$ \\
\hline$M R T(\min )$ & $57.9 \pm 4.63$ & $58.0 \pm 11.5$ & $67.1 \pm 14.6$ \\
\hline$C L(\mathrm{~mL} / \mathrm{min} / \mathrm{kg})$ & $78.4 \pm 13.1$ & $67.9 \pm 11.7$ & $70.4 \pm 9.10$ \\
\hline$C L_{\mathrm{R}}(\mathrm{mL} / \mathrm{min} / \mathrm{kg})^{\mathrm{a}}$ & $1.13 \pm 0.431$ & $1.06 \pm 0.235$ & $0.678 \pm 0.253$ \\
\hline$C L_{\mathrm{NR}}(\mathrm{mL} / \mathrm{min} / \mathrm{kg})$ & $77.2 \pm 12.8$ & $66.8 \pm 11.4$ & $69.7 \pm 9.13$ \\
\hline$V_{\mathrm{ss}}(\mathrm{L} / \mathrm{kg})$ & $4.57 \pm 1.03$ & $4.02 \pm 1.36$ & $4.91 \pm 1.44$ \\
\hline$A e_{0-24 \mathrm{~h}}(\% \text { of dose })^{\mathrm{b}}$ & $1.42 \pm 0.418$ & $1.56 \pm 0.129$ & $0.979 \pm 0.365$ \\
\hline$G I_{24 \mathrm{~h}}(\%$ of dose $)$ & $0.881 \pm 0.411$ & $1.01 \pm 0.731$ & $1.76 \pm 0.958$ \\
\hline$F_{\text {rel }}(\%)$ & - & 114 & 104 \\
\hline Oral Study & $n=5$ & $n=6$ & $n=6$ \\
\hline Body weight (g) & $247 \pm 2.74$ & $244 \pm 6.07$ & $253 \pm 8.54$ \\
\hline$A U C_{\text {last }}(\mu \mathrm{g} \mathrm{min} / \mathrm{mL})^{b}$ & $4.97 \pm 1.44$ & $6.38 \pm 1.60$ & $9.67 \pm 2.05$ \\
\hline$A U C_{\text {inf }}(\mu \mathrm{g} \min / \mathrm{mL})^{\mathrm{b}}$ & $5.21 \pm 1.27$ & $6.94 \pm 1.74$ & $10.9 \pm 3.02$ \\
\hline$C_{\max }(\mu \mathrm{g} / \mathrm{mL})^{\mathrm{c}}$ & $0.0583 \pm 0.0207$ & $0.124 \pm 0.446$ & $0.184 \pm 0.459$ \\
\hline$T_{\max }(\min )$ & $15(5-60)$ & $30(15-30)$ & $30(15-30)$ \\
\hline$C L / F(\mathrm{~mL} / \mathrm{min} / \mathrm{kg})^{\mathrm{b}}$ & $3039 \pm 805$ & $3167 \pm 1021$ & $1803 \pm 515$ \\
\hline$V_{\mathrm{Z}} / F(\mathrm{~L} / \mathrm{kg})^{\mathrm{b}}$ & $670 \pm 170$ & $794 \pm 175$ & $471 \pm 117$ \\
\hline$C L_{\mathrm{R}}(\mathrm{mL} / \mathrm{min} / \mathrm{kg})^{\mathrm{b}}$ & $3.50 \pm 1.10$ & $3.43 \pm 1.15$ & $1.79 \pm 0.474$ \\
\hline$A e_{0-24 h}(\%$ of dose $)$ & $0.103 \pm 0.0510$ & $0.104 \pm 0.0362$ & $0.0870 \pm 0.0383$ \\
\hline$G I_{24 \mathrm{~h}}(\% \text { of dose })^{\mathrm{b}}$ & $41.7 \pm 13.3$ & $36.5 \pm 12.6$ & $20.0 \pm 7.44$ \\
\hline$F_{\mathrm{abs}}(\%)$ & 58.3 & 63.5 & 80.1 \\
\hline$F(\%)$ & 1.97 & 2.29 & 3.96 \\
\hline$F_{\text {rel }}(\%)$ & - & 133 & 209 \\
\hline
\end{tabular}

Data are the mean $\pm S D$. $A U C_{\text {last }}$, total area under the plasma concentration-time curve from time zero to the time of last blood sampling point; $A U C_{\text {inf }}$, total area under the plasma concentration-time curve from time zero to infinity; $M R T$, mean residence time; $C L$, time-averaged total body clearance; $C L_{\mathrm{R}}$, time-averaged renal clearance; $C L_{\mathrm{NR}}$, time-averaged non-renal clearance; $V_{\mathrm{ss}}$, apparent volume of distribution at steady state; $A e_{0-24 \mathrm{~h}}$, percentage of the dose excreted in the urine up to $24 \mathrm{~h} ; G I_{24} \mathrm{~h}$, percentage of the dose recovered from the gastrointestinal tract (including its contents and feces) at $24 \mathrm{~h} ; C_{\max }$, peak plasma concentration of docetaxel; $T_{\max }$, time to reach $C_{\max }$; $C L / F$, apparent oral clearance; $V_{\mathrm{z}} / F$, apparent volume of distribution during elimination; $F_{\text {abs }}$, absorbed fraction of oral dose; $F$, extent of absolute oral bioavailability; $F_{\text {rel }}$, extent of relative bioavailability. ${ }^{\text {a }} 100 \mathrm{mg} / \mathrm{kg} \mathrm{LC} 478$ was significantly different $(p<0.05)$ from $0 \mathrm{mg} / \mathrm{kg} \mathrm{LC} 478$, but not $30 \mathrm{mg} / \mathrm{kg} \mathrm{LC478.} \mathrm{b} 100 \mathrm{mg} / \mathrm{kg}$ LC478 was significantly different $(p<0.05)$ from 0 and $30 \mathrm{mg} / \mathrm{kg}$ LC478. ${ }^{\mathrm{c}}$ All group were significantly different $(p<0.05)$ from each other.

After oral administration of docetaxel with $100 \mathrm{mg} / \mathrm{kg}$ LC478, pharmacokinetic parameters of docetaxel significantly changed as following: $A U C_{\text {last }}$ was significantly greater (by $94.6 \%$ and $51.6 \%$ ), $A U C_{\text {inf }}$ was significantly greater (by $109 \%$ and $57.1 \%$ ), $C_{\max }$ was significantly higher (by $216 \%$ and $48.4 \%$ ), $C L / F$ was significantly slower (by $40.7 \%$ and $43.1 \%$ ), $V_{\mathrm{z}} / F$ was significantly smaller (by $29.7 \%$ and $40.7 \%$ ), $C L_{\mathrm{R}}$ was significantly slower (by $48.9 \%$ and $47.8 \%$ ), and $G I_{24} \mathrm{~h}$ was significantly smaller (by $52 \%$ and $45.2 \%$ ) than those with 0 and $30 \mathrm{mg} / \mathrm{kg} \mathrm{LC} 478$, respectively. In the case of oral administration of docetaxel with $30 \mathrm{mg} / \mathrm{kg}$ LC478, pharmacokinetic parameters of docetaxel, except $C_{\max }$, were not changed compared to those without LC478. The $C_{\max }$ values of docetaxel with 0,30 , and $100 \mathrm{mg} / \mathrm{kg}$ LC478 were significantly different from each other. The $F$ and $F_{\text {rel }}$ of docetaxel with $100 \mathrm{mg} / \mathrm{kg}$ LC478 were considerably increased (by 102\% and 109\%) compared to those without LC478.

\subsection{Effect of LC478 on Bi-Directional Transport of Rhodamine-123 or Docetaxel across Small Intestine in Rats}

Effect of LC478 on $P_{\text {app }}$ values and efflux ratios from bi-directional transport of rhodamine-123 and docetaxel across small intestine are shown in Figure 5 and Table 3. First, rhodamine-123 transport across small intestine was apically polarized because secretory $P_{\text {app }}(\mathrm{S}$ to $\mathrm{M}$ ) value was 5.99-fold higher than 
absorptive $P_{\text {app }}$ (M to S) in the control group. In the presence of $10 \mu \mathrm{M}$ verapamil, the secretory $P_{\text {app }}$ of rhodamine-123 significantly decreased (by 104\%) and consequently, the apically directed polarity in rhodamine-123 transport was considerably attenuated (efflux ratio: $6.21 \rightarrow 1.70$ ) compared with the control group. This suggests that the apically polarized transport of rhodamine- 123 across the small intestine is predominantly facilitated by P-gp rather than other efflux transporters. Interestingly, the apically directed polarity in rhodamine-123 transport with $10 \mu \mathrm{M}$ LC478 was considerably attenuated by secretory $P_{\text {app }}$ reduction (by $118 \%$ ) compared with the control group. These results suggest that P-gp mediated efflux activity of rhodamine- 123 in the small intestine was significantly attenuated by LC478.

Table 3. Absorptive $P_{\text {app }}$, secretory $P_{\text {app }}$, efflux ratio of rhodamine- 123 or docetaxel across the small intestine with various concentrations of LC478 or verapamil.

\begin{tabular}{|c|c|c|c|}
\hline \multirow{2}{*}{ Compounds } & \multicolumn{2}{|c|}{$P_{\text {app }}\left(\times 10^{-6} \mathrm{~cm} / \mathrm{s}\right)$} & \multirow{2}{*}{ Efflux Ratio } \\
\hline & Absorptive (M to $\mathrm{S}$ ) & Secretory (S to $M$ ) & \\
\hline Rhodamine-123 & $n=3$ & $n=3$ & \\
\hline Control & $0.105 \pm 0.0387$ & $0.629 \pm 0.160^{a}$ & 5.99 \\
\hline $1 \mu \mathrm{M}$ LC478 & $0.103 \pm 0.0472$ & $0.577 \pm 0.0791^{\mathrm{a}}$ & 5.60 \\
\hline $10 \mu \mathrm{M}$ LC478 & $0.188 \pm 0.0177$ & $0.288 \pm 0.108^{b}$ & 1.53 \\
\hline $10 \mu \mathrm{M}$ verapamil & $0.191 \pm 0.0562$ & $0.308 \pm 0.113^{b}$ & 1.61 \\
\hline Docetaxel & $n=3$ & $n=3$ & \\
\hline Control & $0.174 \pm 0.0721$ & $1.08 \pm 0.115^{\mathrm{a}}$ & 6.21 \\
\hline $1 \mu \mathrm{M}$ LC478 & $0.171 \pm 0.0639$ & $0.943 \pm 0.283^{a}$ & 5.51 \\
\hline $10 \mu \mathrm{M}$ LC478 & $0.262 \pm 0.0139^{b}$ & $0.574 \pm 0.101^{\mathrm{a}, \mathrm{b}}$ & 2.19 \\
\hline $10 \mu \mathrm{M}$ verapamil & $0.230 \pm 0.0303^{b}$ & $0.408 \pm 0.0959^{\mathrm{a}, \mathrm{b}}$ & 1.77 \\
\hline
\end{tabular}

Data are the mean \pm SD. $P_{\text {app }}$, permeability coefficient; efflux ratio, the ratio of secretory $P_{\text {app }}$ to absorptive

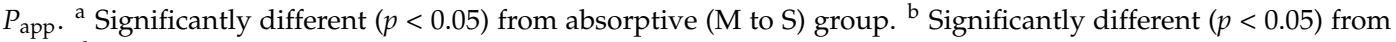
control group.
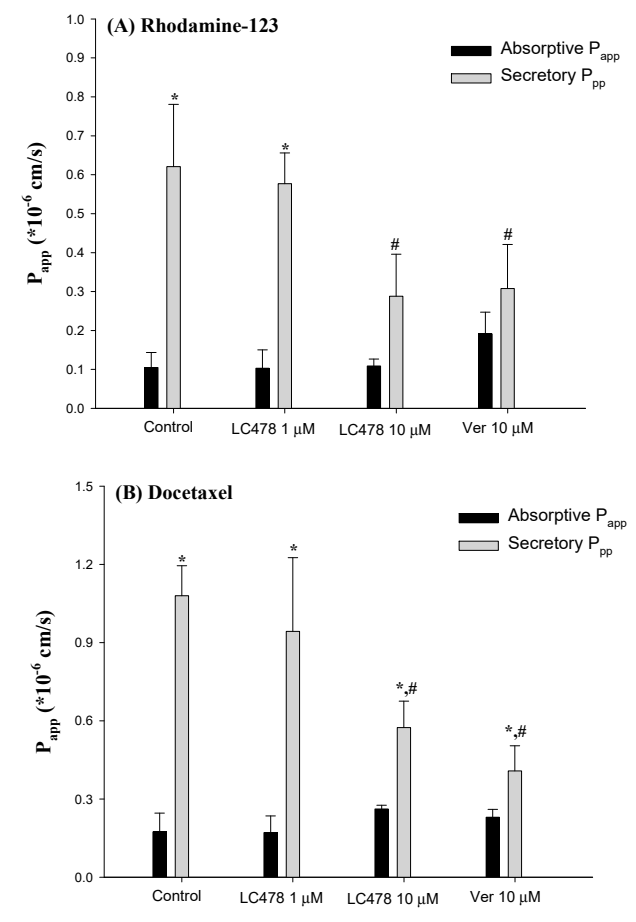

Figure 5. Absorptive $P_{\text {app }}(\mathbf{\square})$ and secretory $P_{\text {app }}(\mathbf{\square})$ of Rhodamine-123 (A) or docetaxel (B) across the rat small intestine with various concentrations of verapamil or LC478. Vertical bar represents SD. * Significantly different $(p<0.05)$ from absorptive $(\mathrm{M}$ to $\mathrm{S})$ group. ${ }^{\#}$ Significantly different $(p<0.05)$ from control group. 
We observed a similar tendency with bi-directional transport of docetaxel. In the control group, secretory Papp was 6.21-fold higher than absorptive $P_{\text {app }}$, indicating that docetaxel transport across the small intestine was apically polarized. In the presence of $10 \mu \mathrm{M}$ verapamil or LC478, the secretory $P_{\text {app }}$ of docetaxel significantly decreased (by 165 or $88.2 \%$ ), indicating that apically polarized transport of docetaxel across the small intestine was considerably attenuated by LC478. Consequently, the efflux ratios of docetaxel with $10 \mu \mathrm{M}$ verapamil or $10 \mu \mathrm{M}$ LC478 were reduced compared with those in the control group (efflux ratio changes: $6.79 \rightarrow 2.00$ or $6.79 \rightarrow 2.19$ ), suggesting that P-gp mediated docetaxel efflux across the small intestine might be inhibited by LC478.

\subsection{Effect of LC478 for Docetaxel Metabolism in Liver and Small Intestine}

We investigated the effect of LC478 on docetaxel metabolism by examining kinetics for docetaxel disappearance with various concentrations of LC478 in rat hepatic and intestinal microsomes (Figure 6 and Table 4). The $V_{\max }$ values of docetaxel were similar regardless of LC478 concentrations in hepatic microsomes, suggesting that the maximum velocity for the disappearance (primarily metabolism) of docetaxel was not influenced by LC478. Furthermore, the constant $K_{\mathrm{m}} \mathrm{s}$ of docetaxel with and without LC478 in the hepatic microsomes suggested that the enzyme(s) affinity with docetaxel was not altered by LC478. As a result, LC478 did not change $C L_{\text {int }}$ of docetaxel in hepatic microsomes. LC478 also did not later $V_{\max }, K_{\mathrm{m}}$, and $C L_{\mathrm{int}} \mathrm{s}$ of docetaxel in intestinal microsomes. Thus, hepatic and intestinal metabolism of docetaxel were not inhibited by LC478 in this study.
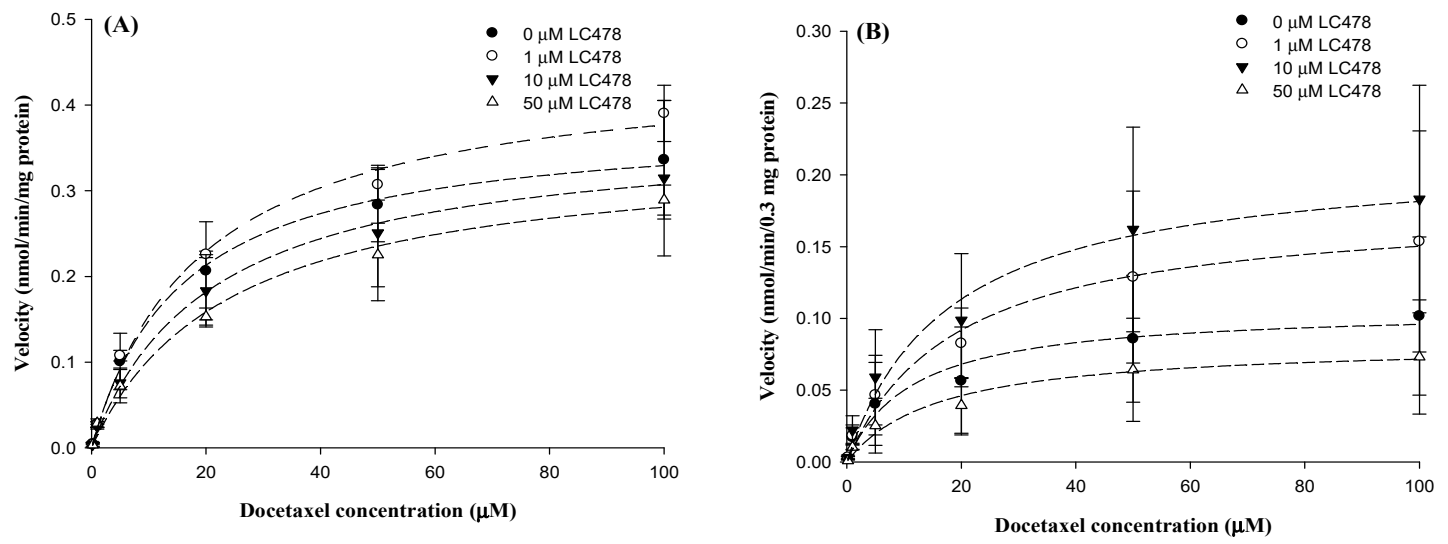

Figure 6. The graph for velocity versus docetaxel concentrations in hepatic (A) and intestinal (B) microsomes. Symbols represent LC478 concentrations: $0(\bullet ; n=3), 1(\bigcirc ; n=3), 10(\mathbf{\nabla} ; n=3)$ and $50(\Delta$; $n=3) \mu \mathrm{M}$ LC478. Vertical bar represents SD.

Table 4. $K_{\mathrm{m}}, V_{\max }$, and $C L_{\mathrm{int}}$ for the disappearance of docetaxel with or without LC478 in hepatic and intestinal microsomes.

\begin{tabular}{lcccc}
\hline \multicolumn{1}{c}{ Parameters } & \multicolumn{4}{c}{ Concentrations of LC478 $(\boldsymbol{\mu M})$} \\
\cline { 2 - 5 } & $\mathbf{0}$ & $\mathbf{1}$ & $\mathbf{5}$ & $\mathbf{1 0}$ \\
\hline Hepatic microcomes & $n=3$ & $n=3$ & $n=3$ & $n=3$ \\
$K_{\mathrm{m}}(\mu \mathrm{M})$ & $20.2 \pm 2.78$ & $20.6 \pm 2.09$ & $21.4 \pm 2.65$ & $23.1 \pm 1.74$ \\
$V_{\max }(\mathrm{nmol} / \mathrm{min} / \mathrm{mg}$ protein $)$ & $0.464 \pm 0.107$ & $0.461 \pm 0.0474$ & $0.438 \pm 0.0578$ & $0.427 \pm 0.0411$ \\
$C L_{\text {int }}(\mu \mathrm{L} / \mathrm{min} / \mathrm{mg}$ protein) & $0.0229 \pm 0.00204$ & $0.0226 \pm 0.00454$ & $0.0206 \pm 0.00280$ & $0.0187 \pm 0.00314$ \\
Intestinal microsomes & $n=3$ & $n=3$ & $n=3$ & $n=3$ \\
$K_{\mathrm{m}}(\mu \mathrm{M})$ & $18.1 \pm 1.20$ & $18.3 \pm 7.07$ & $20.2 \pm 8.94$ & $17.4 \pm 1.01$ \\
$V_{\text {max }}(\mathrm{nmol} / \mathrm{min} / 0.3$ mg protein $)$ & $0.109 \pm 0.0502$ & $0.133 \pm 0.0343$ & $0.133 \pm 0.0737$ & $0.105 \pm 0.0355$ \\
$C L_{\text {int }}(\mu \mathrm{L} / \mathrm{min} / 0.3$ mg protein $)$ & $0.00603 \pm 0.00291$ & $0.00767 \pm 0.00158$ & $0.00757 \pm 0.00559$ & $0.00688 \pm 0.00349$ \\
\hline
\end{tabular}

Data are the mean $\pm \mathrm{SD} . K_{\mathrm{m}}$, the concentration at which the rate is one-half of the $V_{\max } ; V_{\max }$, maximum velocity; $C L_{\text {int }}$, intrinsic clearance. 


\subsection{Effect of LC478 on Rat Plasma Protein Binding of Docetaxel Using Equilibrium Dialysis}

Bound fractions of docetaxel with $0,0.1$ and $10 \mu \mathrm{g} / \mathrm{mL}$ LC478 to fresh rat plasma were $30.6 \% \pm 11.5 \%, 33.4 \% \pm 3.59 \%$, and $29.7 \% \pm 10.1 \%$, respectively. LC478 did not affect the protein binding of docetaxel in rat plasma.

\section{Discussion}

It has been reported that the absorbed fractions of oral dose in the gastrointestinal tract is well correlated between rats and humans [49]. There are similar levels of P-gp expression between rat mdr1a and human MDR1 and overlapping substrate specificity with similar affinity for numerous P-gp substrates [50]. Moreover, sequential homologies of CYPs are high (more than 65\% for CYP3A subfamily) between rats and humans [51], and conserved regions for P450 reductase, heme and signal peptide generally increase this similarity [31]. Therefore, in vivo and in vitro results using rats in this study can provide a meaningful forecast for changes in oral absorption and pharmacokinetics of docetaxel by co-administration of LC478 in humans.

LC478 showed potent inhibitory effects on P-gp mediated efflux along with CYP3A-mediated metabolism of paclitaxel without unexpected intrinsic side effects from MES-SA/DX5 sarcoma cells [34]. After the negligible intrinsic cytotoxicity of LC478 $(0.001-100 \mu \mathrm{M})$ for $24 \mathrm{~h}$ in Caco-2 cells was confirmed, the effect of LC478 on P-gp activity was investigated. Firstly, IC 50 of LC478 for P-gp activity (represented by $E C_{50}$ of LC478 for increasing rhodamine-123 accumulation) in Caco-2 cells $(2.78 \mu \mathrm{M})$ was similar to that of verapamil $(1.67 \mu \mathrm{M})$ in Figure 2B, indicating that LC478 inhibited P-gp activity in Caco-2 cells. In addition, the $I C_{50}$ of LC478, $0.601 \mu \mathrm{M}$, for P-gp mediated efflux of docetaxel in Caco-2 cells (Figure 3) suggested that LC478 has the potential to overcome the intestinal absorption of docetaxel via P-gp efflux.

In in vivo pharmacokinetic studies, sufficient concentration of P-gp inhibitor is required to inhibit P-gp mediated efflux on target sites (e.g., intestine) [37,52]. However, there was no information about LC478 pharmacokinetics and then 30 and $100 \mathrm{mg} / \mathrm{kg}$ of LC478 were arbitrarily adjusted to investigate the effect of LC478 on P-gp inhibition. In case of docetaxel, $20 \mathrm{mg} / \mathrm{kg}$ of docetaxel was selected because 2-20 mg/ $\mathrm{kg}$ and 20-100 $\mathrm{mg} / \mathrm{kg}$ of docetaxel showed the linear pharmacokinetic profiles in rats [37].

The contribution of gastrointestinal (including biliary) excretion of unchanged docetaxel to $C L_{N R}$ of the drug was almost negligible; the $G_{24} \mathrm{~h}$ was less than $1.76 \%$ of the intravenous dose (Table 2). Similarly, it has been reported that docetaxel is mainly eliminated via hepatic metabolism and the biliary excretion of docetaxel as a parent form into feces was negligible [13]. Thus, the $C L_{N R}$ of docetaxel (Table 2) could represent its metabolic clearance. In the intravenous study, unchanged $C L_{N R}$ of docetaxel without LC478 compared to those with 30 and $100 \mathrm{mg} / \mathrm{kg}$ LC478 (Table 2) suggested that LC478 did not alter docetaxel metabolism.

Because docetaxel is a low hepatic excretion drug [53], its hepatic clearance (metabolism) depends on the hepatic intrinsic clearance and the free (unbound to plasma proteins) fraction in the plasma [54]. At this point, the unchanged $C L_{\mathrm{NR}}$ of docetaxel with 30 or $100 \mathrm{mg} / \mathrm{kg}$ LC478 (Table 2) could have been supported by in vitro unchanged hepatic $C L_{\text {int }}$ of docetaxel and free fraction of docetaxel in plasma without LC478 compared to those with LC478 (Table 4). Additionally, $K_{\mathrm{m}}$ and $V_{\max }$ values of docetaxel with 1,5, and $10 \mu \mathrm{M}$ LC478 were not changed compared to those without LC478 in in vitro hepatic microsomal studies (Table 4), indicating that LC478 did not affect the affinity between metabolic enzyme and docetaxel as well as the maximum rate of the metabolism of docetaxel.

In renal excretion of docetaxel, $A e_{0-24 \mathrm{~h}}$ of docetaxel was a very small portion of the docetaxel dose (less than $1.56 \%$ of dose; Table 2). Despite the negligible contribution of $C L_{\mathrm{R}}$ to $C L$ (less than $1.56 \%$; Table 2), LC478 seemed to affect renal excretion of docetaxel in rats. Interestingly, the estimated $C L_{\mathrm{R}}$ of docetaxel considering the free fractions of docetaxel in the plasma $\left(C L_{\mathrm{R}, f u}\right)$ values are $5.04,5.15$, and $2.55 \mathrm{~mL} / \mathrm{min} / \mathrm{kg}$ with 0,30 , and $100 \mathrm{mg} / \mathrm{kg}$ of $\mathrm{LC} 478$, respectively. The $C L_{\mathrm{R}, \mathrm{fu}}$ of docetaxel without LC478 was similar to the reported glomerular filtration rate (GRF, represented by creatinine clearance, $5.24 \mathrm{~mL} / \mathrm{min} / \mathrm{kg}$ ) in rats [55], indicating that docetaxel is excreted via glomerular filtration into urine. 
Furthermore, $30 \mathrm{mg} / \mathrm{kg}$ LC478 seemed not to change the mechanism of renal excretion of docetaxel because $C L_{\mathrm{R} \text {,fu }}$ of docetaxel with $30 \mathrm{mg} / \mathrm{kg}$ LC478 was as similar as creatinine clearance. However, $C L_{\mathrm{R}, \mathrm{fu}}$ of docetaxel with $100 \mathrm{mg} / \mathrm{kg} \mathrm{LC} 478,2.55 \mathrm{~mL} / \mathrm{min} / \mathrm{kg}$, slowed compared to the creatinine clearance in rats [10], indicating that $100 \mathrm{mg} / \mathrm{kg}$ of LC478 might incur reabsorption of docetaxel in rat's renal tubules. Although $100 \mathrm{mg} / \mathrm{kg}$ LC478 increased renal reabsorption of docetaxel, it did not affect the systemic exposure (e.g., AUC) of docetaxel (Table 2).

In the oral study, the greater $A U C_{\text {inf }}, F$ and $F_{\text {rel }}$ of docetaxel with $100 \mathrm{mg} / \mathrm{kg}$ LC478 than those with 0 and $30 \mathrm{mg} / \mathrm{kg}$ of LC478 (Table 2) suggested that LC478 might inhibit P-gp mediated efflux and/or metabolism of docetaxel in intestine. Although the incomplete docetaxel from the gastrointestinal tract in rats brought the extremely low $F_{\text {rel }} \mathrm{s}$ of docetaxel (Table 2), the absorbed fractions of docetaxel were differently changed by co-administration with various doses of LC478. For comparison, we estimated the mean "true" unabsorbed fractions ( $\left.F_{\text {unabs }}\right)$ after oral docetaxel to rats without and with LC478 based on the following reported equation [49];

$$
\begin{array}{lc}
0.417=F_{\text {unabs }}+(0.00881 \times 0.0197) & 0 \mathrm{mg} / \mathrm{kg} \text { oral LC478 } \\
0.365=F_{\text {unabs }}+(0.0101 \times 0.0229) & 30 \mathrm{mg} / \mathrm{kg} \text { oral LC478 } \\
0.200=F_{\text {unabs }}+(0.0176 \times 0.0396) & 100 \mathrm{mg} / \mathrm{kg} \text { oral LC478 }
\end{array}
$$

in which, 0.417 (0.365 and 0.200), 0.00881 (0.0101 and 0.0176), and 0.0197 (0.0229 and 0.0396) are the $\mathrm{GI}_{24 \mathrm{~h}}$ after oral and intravenous administration, and $F$, respectively, with $0 \mathrm{mg} / \mathrm{kg} \mathrm{LC478} \mathrm{(30} \mathrm{and}$ $100 \mathrm{mg} / \mathrm{kg} \mathrm{LC} 478$ ). The ' $F_{\text {unabs' }}$ values thus estimated were $41.7,36.5$, and $20.0 \%$ for with 0,30 , and $100 \mathrm{mg} / \mathrm{kg}$ of LC478, respectively. Thus, the increased gastrointestinal absorption of oral docetaxel with $100 \mathrm{mg} / \mathrm{kg} \mathrm{LC} 478$ could be responsible for the greater $A U C_{\text {inf }}$ of docetaxel than those with 0 and $30 \mathrm{mg} / \mathrm{kg}$ LC478 (Table 2). Especially, the ratio of $A U C$ with inhibitor $\left(A U C_{\mathrm{i}}\right) / A U C$ without inhibitor $\left(A U C_{0}\right)>1.25$ is classified as the relevant drug interaction by inhibitor in U.S. FDA criteria [27,40]. In Table 2, $F_{\text {rel }}$ values in rats with $100 \mathrm{mg} / \mathrm{kg}$ LC478, 209\%, supported that $100 \mathrm{mg} / \mathrm{kg}$ LC478 caused pharmacokinetic interaction of docetaxel via P-gp inhibition.

To further investigate the mechanism for the enhanced gastrointestinal absorption of docetaxel by LC478, the ussing chamber studies the rat's small intestine was performed. It has been reported that P-gp mediated efflux involves the apically-polarized transport of docetaxel [29,32]. In Table 2 and Figure 4, LC478 or verapamil did not alter the apically polarized transport of rhodamine-123, a representative P-gp substrate, or docetaxel across small intestine in rats. However, the secretary permeability of rhodamine- 123 or docetaxel was considerably attenuated by $10 \mu \mathrm{M}$ verapamil and $10 \mu \mathrm{M}$ of LC478. These results suggest that LC478 could enhance the gastrointestinal absorption of docetaxel at least partly by inhibiting P-gp mediated efflux. Moreover, only $10 \mu \mathrm{M}$ LC478 reduced the secretary transport of rhodamine- 123 or docetaxel across the small intestine, indicating that a sufficient concentration of LC478 $(10 \mu \mathrm{M})$ might be required to inhibit P-gp mediated efflux of docetaxel. LC478 concentrations in the intestine after oral administration of 30 and $100 \mathrm{mg} / \mathrm{kg}$ LC478 were $3.25-5.18 \mu \mathrm{M}$ and 9.37-12.3 $\mu \mathrm{M}$ (our unpublished data), respectively. Namely that LC478 concentrations in the intestine from oral administration of $100 \mathrm{mg} / \mathrm{kg}$ LC478 were close to $10 \mu \mathrm{M}$, which might sufficiently inhibit the intestinal P-gp activities to efflux docetaxel.

According to the FDA criteria [56,57], the [I]/IC 50 value was used to predict the P-gp inhibition related drug interaction. In this case, [I] represents gut concentration of the inhibitor and [I]/IC $50>10$ is considered as the P-gp inhibition-mediated drug interaction happens in intestinal tract [56,57]. When [I] is LC478 concentration in the intestine after oral administration of $100 \mathrm{mg} / \mathrm{kg}$ LC478, 9.37-12.3 $\mu \mathrm{M}$ (our unpublished data) and $I C_{50}$ is $0.601 \mu \mathrm{M}$ (Figure 3), [I]/IC $C_{50}$ values were 15.6-20.5. These estimated values suggested that a sufficient concentration of LC478 remains in intestinal tract when $100 \mathrm{mg} / \mathrm{kg}$ of LC478 was orally administered. However, [I] $/$ IC $_{50}$ values from oral administration of $30 \mathrm{mg} / \mathrm{kg}$ LC478 were 5.41-8.62. This result also supported that only $100 \mathrm{mg} / \mathrm{kg}$ of LC478 enhanced the gastrointestinal absorption of docetaxel; the absorbed fraction of docetaxel in the gastrointestinal tract with $100 \mathrm{mg} / \mathrm{kg}$ LC478 was larger than those with 0 and $30 \mathrm{mg} / \mathrm{kg}$ LC478 ( 0.801 versus 0.583 and 0.635 , respectively). 
Thus, a sufficient amount (or concentration) of LC478 seemed to be required to inhibit P-gp for docetaxel absorption.

In the aspect of metabolism, there was no change of $C L_{\text {int }}$ values of docetaxel with 1,5 , and $10 \mu \mathrm{M}$ LC478 compared to that of LC478 alone in vitro intestinal microsomal study (Table 4), supporting that LC478 did not affect intestinal metabolism of docetaxel. Therefore, the greater AUC, $F$ and $F_{\text {rel }}$ after oral docetaxel administration with $100 \mathrm{mg} / \mathrm{kg}$ LC478 were because that LC478 sufficiently increased intestinal absorption of docetaxel via P-gp inhibition.

\section{Conclusions}

LC478 (100 mg/kg, not $30 \mathrm{mg} / \mathrm{kg}$ ) increased intestinal absorption of docetaxel via P-gp inhibition, leading to an increase in oral bioavailability of docetaxel in rats. These results demonstrated the feasibility of LC478 as an ideal bioavailability enhancer for drugs with low absorption manners. Further toxicological and clinical evaluations of LC478 will confer a potential of LC478 as a P-gp inhibitor.

Author Contributions: Conceptualization, K.L. and Y.H.C.; methodology, Y.H.C.; investigation, S.Y.H.; resources, Q.L. and K.L.; writing-original draft preparation, S.Y.H., K.L. and Y.H.C.; writing—review and editing, S.Y.H., K.L., and Y.H.C.; supervision K.L. and Y.H.C.

Funding: This research was funded by the Convergence of Conventional Medicine and Medicine R\&D program funded by National Research Foundation of Korea (NRF) grant funded by the Korea government (MSIT) (NRF-2016R1C1B2010849 and NRF-2018R1A5A2023127).

Conflicts of Interest: The authors declare no conflict of interest.

\section{References}

1. Clarke, S.J.; Rivory, L.P. Clinical pharmacokinetics of docetaxel. Clin. Pharmacokinet. 1999, 36, 99-144. [CrossRef] [PubMed]

2. van Waterschoot, R.A.; Lagas, J.S.; Wagenaar, E.; van der Kruijssen, C.M.; van Herwaarden, A.E.; Song, J.Y.; Rooswinkel, R.W.; van Tellingen, O.; Rosing, H.; et al. Absence of both cytochrome P450 3A and P-glycoprotein dramatically increases docetaxel oral bioavailability and risk of intestinal toxicity. Cancer Res. 2009, 23, 8996-9002. [CrossRef] [PubMed]

3. Gelderblom, H.; Verweij, J.; Nooter, K.; Sparreboom, A. Cremophor EL: The drawbacks and advantages of vehicle selection for drug formulation. Eur. J. Cancer 2001, 37, 1590-1598. [CrossRef]

4. Marks, D.H.; Qureshi, A.; Friedman, A. Evaluation of Prevention Interventions for Taxane-Induced Dermatologic Adverse Events: A Systematic Review. JAMA Dermatol. 2018, 154, 1465-1472. [CrossRef]

5. Sohail, M.F.; Rehman, M.; Sarwar, H.S.; Naveed, S.; Salman, O.; Bukhari, N.I.; Hussain, I.; Webster, T.J.; Shahnaz, G. Advancements in the oral delivery of Docetaxel: Challenges, current state-of-the-art and future trends. Int. J. Nanomed. 2018, 13, 3145-3161. [CrossRef]

6. DeMario, M.D.; Ratain, M.J. Oral chemotherapy: Rationale and future directions. J. Clin. Oncol. 1998, 16, 2557-2567. [CrossRef] [PubMed]

7. Baker, S.D.; Sparreboom, A.; Verweij, J. Clinical pharmacokinetics of docetaxel: Recent developments. Clin. Pharmacokinet. 2006, 45, 235-252. [CrossRef]

8. Cho, H.J.; Park, J.W.; Yoon, I.S.; Kim, D.D. Surface-modified solid lipid nanoparticles for oral delivery of docetaxel: Enhanced intestinal absorption and lymphatic uptake. Int. J. Nanomed. 2014, 9, 495-504.

9. Dong, Y.; Feng, S.S. Poly(D,L-lactide-co-glycolide)/montmorillonite nanoparticles for oral delivery of anticancer drugs. Biomaterials 2005, 26, 6068-6076. [CrossRef]

10. Ben Reguiga, M.; Bonhomme-Faivre, L.; Farinotti, R. Bioavailability and tissular distribution of docetaxel, a P-glycoprotein substrate, are modified by interferon-alpha in rats. J. Pharm. Pharmacol. 2007, 59, 401-408. [CrossRef]

11. Malingré, M.M.; Richel, D.J.; Beijnen, J.H.; Rosing, H.; Koopman, F.J.; Ten Bokkel Huinink, W.W.; Schot, M.E.; Schellens, J.H. Co-administration of cyclosporine strongly enhances the oral bioavailability of docetaxel. J. Clin. Oncol. 2001, 19, 1160-1166. [CrossRef] [PubMed] 
12. Shirakawa, K.; Takara, K.; Tanigawara, Y.; Aoyama, N.; Kasuga, M.; Komada, F.; Sakaeda, T.; Okumura, K. Interaction of docetaxel ("Taxotere") with human P-glycoprotein. Jpn. J. Cancer Res. 1999, 90, 1380-1386. [CrossRef] [PubMed]

13. Sparreboom, A.; van Tellingen, O.; Nooijen, W.J.; Beijnen, J.H. Preclinical pharmacokinetics of paclitaxel and docetaxel. Anticancer Drugs 1998, 9, 1-17. [CrossRef] [PubMed]

14. Varma, M.V.; Ashokraj, Y.; Dey, C.S.; Panchagnula, R. P-glycoprotein inhibitors and their screening: A perspective from bioavailability enhancement. Pharmacol. Res. 2003, 48, 347-359. [CrossRef]

15. Veber, D.F.; Johnson, S.R.; Cheng, H.Y.; Smith, B.R.; Ward, K.W.; Kopple, K.D. Molecular properties that influence the oral bioavailability of drug candidates. J. Med. Chem. 2002, 12, 2615-2623. [CrossRef]

16. Kenmotsu, H.; Tanigawara, Y. Pharmacokinetics, dynamics and toxicity of docetaxel: Why the Japanese dose differs from the Western dose. Cancer Sci. 2015, 106, 497-504. [CrossRef]

17. Yu, H.; Hendrikx, J.J.; Rottenberg, S.; Schellens, J.H.; Beijnen, J.H.; Huitema, A.D. Development of a Tumour Growth Inhibition Model to Elucidate the Effects of Ritonavir on Intratumoural Metabolism and Anti-tumour Effect of Docetaxel in a Mouse Model for Hereditary Breast Cancer. AAPS J. 2016, 18, 362-371. [CrossRef]

18. Chen, S.; Sutiman, N.; Zhang, C.Z.; Yu, Y.; Lam, S.; Khor, C.C.; Chowbay, B. Pharmacogenetics of irinotecan, doxorubicin and docetaxel transporters in Asian and Caucasian cancer patients: A comparative review. Drug Metab. Rev. 2016, 48, 502-540. [CrossRef] [PubMed]

19. Chung, F.S.; Santiago, J.S.; Jesus, M.F.; Trinidad, C.V.; See, M.F. Disrupting P-glycoprotein function in clinical settings: What can we learn from the fundamental aspects of this transporter? Am. J. Cancer Res. 2016, 6, 1583-1598.

20. Saneja, A.; Khare, V.; Alam, N.; Dubey, R.D.; Gupta, P.N. Advances in P-glycoprotein-based approaches for delivering anticancer drugs: Pharmacokinetic perspective and clinical relevance. Expert Opin. Drug Deliv. 2014, 11, 121-138. [CrossRef]

21. Sun, X.; Li, J.; Guo, C.; Xing, H.; Xu, J.; Wen, Y.; Qiu, Z.; Zhang, Q.; Zheng, Y.; Chen, X.; et al. Pharmacokinetic effects of curcumin on docetaxel mediated by OATP1B1, OATP1B3 and CYP450s. Drug Metab. Pharmacokinet. 2016, 31, 269-275. [CrossRef]

22. Fojo, A.T.; Ueda, K.; Slamon, D.J.; Poplack, D.G.; Gottesman, M.M.; Pastan, I. Expression of a multidrug-resistance gene in human tumors and tissues. Proc. Natl. Acad. Sci. USA 1987, 84, 265-269. [CrossRef] [PubMed]

23. Saaby, L.; Brodin, B. A critical view on in vitro analysis of P-glycoprotein (P-gp) transport kinetics. J. Pharm. Sci. 2017, 106, 2257-2264. [CrossRef] [PubMed]

24. Chen, L.; Li, Y.; Yu, H.; Zhang, L.; Hou, T. Computational models for predicting substrates or inhibitors of P-glycoprotein. Drug Discov. Today 2012, 17, 343-351. [CrossRef] [PubMed]

25. Dou, L.; Mai, Y.; Madla, C.M.; Orlu, M.; Basit, A.W. P-glycoprotein expression in the gastrointestinal tract of male and female rats is influenced differently by food. Eur. J. Pharm. Sci. 2018, 123, 569-575. [CrossRef] [PubMed]

26. Kwak, J.O.; Lee, S.H.; Lee, G.S.; Kim, M.S.; Ahn, Y.G.; Lee, J.H.; Kim, S.W.; Kim, K.H.; Lee, M.G. Selective inhibition of MDR1 (ABCB1) by HM30181 increases oral bioavailability and therapeutic efficacy of paclitaxel. Eur. J. Pharmacol. 2010, 627, 92-98. [CrossRef] [PubMed]

27. Kuppens, I.E.; Bosch, T.M.; van Maanen, M.J.; Rosing, H.; Fitzpatrick, A.; Beijnen, J.H.; Schellens, J.H. Oral bioavailability of docetaxel in combination with OC144-093 (ONT-093). Cancer Chemother. Pharmacol. 2005, 55, 72-78. [CrossRef]

28. Oostendorp, R.L.; Huitema, A.; Rosing, H.; Jansen, R.S.; Ter Heine, R.; Keessen, M.; Beijnen, J.H.; Schellens, J.H. Coadministration of ritonavir strongly enhances the apparent oral bioavailability of docetaxel in patients with solid tumors. Clin. Cancer Res. 2009, 15, 4228-4233. [CrossRef]

29. Engels, F.K.; Sparreboom, A.; Mathot, R.A.; Verweij, J. Potential for improvement of docetaxel-based chemotherapy: A pharmacological review. Br. J. Cancer 2005, 93, 173-177. [CrossRef]

30. Prueksaritanont, T.; Tatosian, D.A.; Chu, X.; Railkar, R.; Evers, R.; Chavez-Eng, C.; Lutz, R.; Zeng, W.; Yabut, J.; Chan, G.H.; et al. Validation of a microdose probe drug cocktail for clinical drug interaction assessments for drug transporters and CYP3A. Clin. Pharmacol. Ther. 2017, 101, 519-530. [CrossRef]

31. Soucek, P.; Gut, I. Cytochromes P-450 in rats: Structures, functions, properties and relevant human forms. Xenobiotica 1992, 22, 83-103. [CrossRef] [PubMed] 
32. Yan, Y.D.; Kim, D.H.; Sung, J.H.; Yong, C.S.; Choi, H.G. Enhanced oral bioavailability of docetaxel in rats by four consecutive days of pre-treatment with curcumin. Int. J. Pharm. 2010, 399, 116-120. [CrossRef] [PubMed]

33. Min, K.H.; Xia, Y.; Kim, E.K.; Kaur, N.; Kim, E.S.; Kim, D.K.; Jung, H.Y.; Choi, Y.; Park, M.K.; Min, Y.K.; et al. A novel class of highly potent multidrug resistance reversal agents: Disubstituted adamantyl derivatives. Bioorg. Med. Chem. Lett. 2009, 19, 5376-5379. [CrossRef] [PubMed]

34. Zhang, J.; Huang, M.; Guan, S.; Bi, H.C.; Pan, Y.; Duan, W.; Chan, S.Y.; Chen, X.; Hong, Y.H.; Bian, J.S.; et al. A mechanistic study of the intestinal absorption of cryptotanshinone, the major active constituent of Salvia miltiorrhiza. J. Pharmacol. Exp. Ther. 2006, 317, 1285-1294. [CrossRef] [PubMed]

35. Bae, J.K.; Kim, Y.J.; Chae, H.S.; Kim, D.Y.; Choi, H.S.; Chin, Y.W.; Choi, Y.H. Korean red ginseng extract enhances paclitaxel distribution to mammary tumors and its oral bioavailability by P-glycoprotein inhibition. Xenobiotica 2017, 47, 450-459. [CrossRef] [PubMed]

36. Bentz, J.; O’Connor, M.P.; Bednarczyk, D.; Coleman, J.; Lee, C.; Palm, J.; Pak, Y.A.; Perloff, E.S.; Reyner, E.; Balimane, P.; et al. Variability in P-glycoprotein inhibitory potency $\left(\mathrm{IC}_{50}\right)$ using various in vitro experimental systems: Implications for universal digoxin drug-drug interaction risk assessment decision criteria. Drug Metab. Dispos. 2013, 41, 1347-1366. [CrossRef] [PubMed]

37. Choi, Y.H.; Yoon, I.; Kim, T.G.; Lee, M.G. Effects of cysteine on the pharmacokinetics of docetaxel in rats with protein-calorie malnutrition. Xenobiotica 2012, 42, 442-455. [CrossRef] [PubMed]

38. Kishimoto, W.; Ishiguro, N.; Ludwig-Schwellinger, E.; Ebner, T.; Maeda, K.; Sugiyama, Y. Usefulness of A Model-Based Approach for Estimating In Vitro P-Glycoprotein Inhibition Potency in a Transcellular Transport Assay. J. Pharm. Sci. 2016, 105, 891-896. [CrossRef] [PubMed]

39. Senthilkumari, S.; Velpandian, T.; Biswas, N.R.; Saxena, R.; Ghose, S. Evaluation of the modulation of P-glycoprotein on the intraocular disposition of its substrate in rabbits. Curr. Eye Res 2008, 33, 333-343. [CrossRef]

40. Jia, J.X.; Wasan, K.M. Effects of monoglycerides on rhodamine 123 accumulation, estradiol 17 beta-D-glucuronide bidirectional transport and MRP2 protein expression within Caco-2 cells. J. Pharm. Pharm. Sci. 2008, 11, 45-62. [CrossRef] [PubMed]

41. Gibaldi, M.; Perrier, D. Pharmacokinetics, 2nd ed.; Marcel-Dekker: New York, NY, USA, 1982; p. 494.

42. Benet, L.Z.; Zia-Amirhosseini, P. Basic principles of pharmacokinetics. Toxicol. Pathol. 1995, 23, 115-123. [CrossRef] [PubMed]

43. Toutain, P.L.; Bousquet-Melou, A. Volumes of distribution. J. Vet. Pharmacol. Ther. 2004, 27, 441-453. [CrossRef] [PubMed]

44. Saari, T.I.; Laine, K.; Leino, K.; Valtonen, M.; Neuvonen, P.J.; Olkkola, K.T. Effect of voriconazole on the pharmacokinetics and pharmacodynamics of intravenous and oral midazolam. Clin. Pharmacol. Ther. 2005, 79, 362-370. [CrossRef] [PubMed]

45. Chiou, W.L.; Barve, A. Linear correlation of the fraction of oral dose absorbed of 64 drugs between humans and rats. Pharm. Res. 1998, 15, 1792-1795. [CrossRef]

46. Werle, M.; Hoffer, M. Glutathione and thiolated chitosan inhibit multidrug resistance P-glycoprotein activity in excised small intestine. J. Control Release 2006, 111, 41-46. [CrossRef]

47. Yerasi, N.; Vurimindi, H.; Devarakonda, K. Frog intestinal perfusion to evaluate drug permeability: Application to p-gp and cyp3a4 substrates. Front. Pharmacol. 2015, 14, 141. [CrossRef]

48. Duggleby, R.G. Analysis of enzyme progress curves by nonlinear regression. Methods Enzymol. 1995, 249, 61-90.

49. Lee, M.G.; Chiou, W.L. Evaluation of potential causes for the incomplete bioavailability of furosemide: Gastric first-pass metabolism. J. Pharmacokinet. Biopharm. 1983, 11, 623-640. [CrossRef]

50. Stephens, R.H.; O’Neill, C.A.; Warhurst, A.; Carlson, G.L.; Rowland, M.; Warhurst, G. Kinetic profiling of P-glycoprotein-mediated drug efflux in rat and human intestinal epithelia. J. Pharmacol. Exp. Ther. 2001, 296, 584-591.

51. Lewis, D.F.V. Chapter 4. P450. Substrate specificity and metabolism. In Cytochromes P450, Structure, Function, and Mechanism, 2nd ed.; Taylor \& Fancis: Bristol, PA, USA, 1996; p. 123.

52. Takahashi, R.; Ma, S.; Yue, Q.; Kim-Kang, H.; Yi, Y.; Lyssikatos, J.P.; Regal, K.; Hunt, K.W.; Kallan, N.C.; Siu, M.; et al. Dose-dependent exposure and metabolism of GNE-892, a $\beta$-secretase inhibitor, in monkeys: Contributions by P450, AO, and P-gp. Eur. J. Drug Metab. Pharmacokinet. 2015, 40, 171-185. [CrossRef] 
53. Crommentuyn, K.M.; Schellens, J.H.; van den Berg, J.D.; Beijnen, J.H. In-vitro metabolism of anti-cancer drugs, methods and applications: Paclitaxel, docetaxel, tamoxifen and ifosfamide. Cancer Treat. Rev. 1998, 24, 345-366. [CrossRef]

54. Wilkinson, G.R.; Shand, D.G. Commentary: A physiological approach to hepatic drug clearance. Clin. Pharmacol. Ther. 1975, 18, 377-390. [CrossRef] [PubMed]

55. Davies, B.; Morris, T. Physiological parameters in laboratory animals and humans. Pharm. Res. 1993, 10, 1093-1095. [CrossRef] [PubMed]

56. Jouan, E.; Le Vée, M.; Mayati, A.; Denizot, C.; Parmentier, Y.; Fardel, O. Evaluation of P-Glycoprotein Inhibitory Potential Using a Rhodamine 123 Accumulation Assay. Pharmaceutics 2016, 8, E12. [CrossRef] [PubMed]

57. Poirier, A.; Cascais, A.C.; Bader, U.; Portmann, R.; Brun, M.E.; Walter, I.; Hillebrecht, A.; Ullah, M.; Funk, C. Calibration of in vitro multidrug resistance protein 1 substrate and inhibition assay as a basis to support the prediction of clinically relevant interactions in vivo. Drug Metab. Dispos. 2014, 42, 1411-1422. [CrossRef] [PubMed]

(C) 2019 by the authors. Licensee MDPI, Basel, Switzerland. This article is an open access article distributed under the terms and conditions of the Creative Commons Attribution (CC BY) license (http:/ / creativecommons.org/licenses/by/4.0/). 